\title{
Soil Cover State at Oil Field Construction and its Protection
}

\author{
Yurii V. Sivkov ${ }^{1}$ \\ ${ }^{1}$ Department of Technospheric Safety, Tyumen Industrial University Tyumen, Russia \\ e-mail: tumen_sivkov@mail.ru
}

\begin{abstract}
This article deals with the problems of the soil cover disturbance and contamination at oil field construction. It provides a description of the set of measures aimed at ensuring the soil protection at the construction of industrial facilities at oil fields. The research object was the soil located at the interface of the wooded tundra and the southern tundra. This soil is characterized by the peculiar features that are determined by the certain commonality of the climate, as well as the similarity of the landscape evolution. The work included studying the content of the polluting matters in the tundra marshy and alluvial soddy soil located at the interface of the wooded tundra and southern tundra. The article contains a detailed analysis of the measures aimed at decreasing the impact on the soil cover during the construction of approach ways to valve stations and line facilities. The measures on the reliability and safety improvement of the pipeline operation, preservation of the stream conditions, the measures aimed at the prevention and minimization of the negative impact on the geological environment, and the measures for farsighted use and protection of soil quarries (sand and turf) have also been considered.
\end{abstract}

Keywords: Impurityconcentration, measures, oil,oilandgasindustry, soil, soildisturbance, petrochemicals, pollution.

\section{INTRODUCTION}

The industrial activity related to the oil field development and hydrocarbons transportation negatively affects the soil cover, deteriorating its quality characteristics or destroying it completely (Parfenov \& Sivkov, 2015a).

The main types of impact related to the oil industry include territory alienation; land drainage or flooding; road and communication line construction; soil contamination with oil, petrochemicals, and heavy metals; deforestation and land usage change; changes in the stream conditions of water bodies; the noise, light, vibration, and electromagnetic impact (Tetelmin \& Yazev, 2009; Parfenov \& Sivkov, 2015b).

In the process of oil and gas deposits development and operation, soil is not only subjected to significant mechanical loads, but is also contaminated with oil, petrochemicals, and various chemicals, as well as with highly mineralized stratal and refinery water. Besides, various wastes of the fuel and power industry enterprises, metal junkyards and solid waste deposits also have an adverse impact on the soil state.

The soil contamination with oil takes place during its extraction, transportation, and storage, as well as its processing and application in technological processes. The causes of such contamination are the mechanical damages and physical wear of the equipment. Considering the problem of oil contamination with oil, it can be noted that spills mainly take place near main and local oilfield product pipelines (Podavalov, 2010).

Oil causes changes in the chemical composition of soil, its properties and structure (Amakiri \& Onofeghara, 1984). The amount of carbon in the humus layer increases significantly, which deteriorates the soil property as a nutrient substrate for plants. The hydrophobic particles of oil prevent moisture from coming to the root area of plants, which results in their physiological changes (Hutchinson \& Freedman, 1978).

Soil and ground are affected during the oil field construction. The main impact sources are: 
- motor vehicles, road and construction machinery;

- leakage and emissions of contaminants (fuel and lubricant spills);

- solid and liquid waste of production and consumption;

- construction and erection work;

- construction area back filling.

A significant factor of impact on the land resources is the land acquisition for the placement of construction facilities, as well as their natural state disturbance in the course of the construction and erection work and probable emergency situations.

During the deposit construction, the back filling of the territory for industrial facilities has a direct impact on the soil and ground, which results in the soil layer disturbance and transformation of the existing relief. The surface transformation (formation of positive (earthworks, banks) and negative (trenches, pits) shapes) entails considerable consequences for the natural systems and can result in the changes in the surface and subterranean areas, which in turn causes the vegetative ground cover and fauna transformation, as well as the changes in the snow melting conditions and the groundwater level. During earthwork, the most severe damage to the environment is caused by the erosion processes: the open ground areas are the source of sand and dust. The dust load increases the overall mineralization of the peat deposits in the surrounding marshlands and causes a gradual change in the vegetation. The forest communities of the upland areas also undergo changes due to the same reason, but at a lower degree.

High power and capacity machinery load is transferred to the ground and causes changes in the soil state and properties, which consequently results in the development of supergene processes, such as erosion and deflation, which are not typical of non-disturbed soil covers, as well as in the disturbance of the habitat of soil organisms.

\section{MATERIAL AND METHODS}

The work included the study on the soil cover state at the construction site of an oil deposit and the measures for its preservation. The study object is located at the interface of the wooded tundra and southern tundra, which cover large areas in the north of Russia and are characterized by common features of the soil cover due to the similar climate, as well as landscape evolution. The common feature of the area is the slowed down biological cycle, which does not lead to intensive peat formation due to insignificant gain in the vegetation and small quantity of tree waste. The surface location of the root systems of the majority of plants as well as the shallow penetration of moss and lichen rhizoids into the cold soil limits the capability of plants to use the mineral nutrition elements and is one of the causes of the low ash content of the phytomass.

The wooded tundra area is characterized by a severe climate. The duration of the vegetation period (at a temperature above $+5^{\circ} \mathrm{C}$ ) is very short, between 95 and 110 days a year. Precipitation amounts to 400 to $600 \mathrm{~mm}$ a year. Nevertheless, the soil suffers from water saturation. The latter is explained by the low air temperature in summer and high relative humidity of the summer air. The permafrost, which is not very deep, considerably impacts the soil saturation with water, as it prevents the quick melting and warming of tundra soil, hinders filtration, and maintains its high humidity (Shumanova, 1965; Cherkashenina, 1972).

Considerable peculiarities of soil formation in the wooded tundra area are connected to the diverse impact of cryogenic processes, which determine not only the soil properties, but also the peculiar features of the soil cover. Total development of frost heave processes results in the formation of two different types of the mesorelief: flat hill peat deposits and heave hills within both bottomland and terrain landscapes.

The soil formation rocks most often are loamy, weakly pebble, morainal, sabulous, and sandy sediments. The following soil types and systems are common across the research territory (Egorov, 1977; Bezuglova, 2009):

- alluvial sod-gley;

- tundra marshy peaty-gley.

The tundra marshy soils cover leveled depressions, flat leveled areas, as well as slight depressions of the microrelief, where permanent moistening creates the conditions for the accumulation of considerable amount of poorly decomposed organic residuals that form the peat layers of tundra marshy soil. Due to the shallow defrosting of soil, the heavy mechanical structure of soil-forming rocks, permanent water saturation of soil, and lack of mineral layer oxidation periods, the gleying processes are rather distinct. The 
soil formation is connected with the accumulation of semidecomposed organic residues (peat) under the conditions of excessive moistening with groundwater. The soil is mainly represented with shallow or medium-depth lowland peat deposits.

Depending on the depth of the peat layer, the marshy tundra soil is divided into three subtypes:

- marshy tundra peat-like-gley soil (the depth of the humus peaty layer is up to $0.20 \mathrm{~m}$ );

- marshy tundra peat-gley soil (the depth of the humus peaty layer is between 0.2 and $0.5 \mathrm{~m}$ );

- marshy tundra peaty soil (the depth of the humus peaty layer is above $0.5 \mathrm{~m}$ ).

The type of the alluvial soil is characterized by their regular (not necessarily yearly) flooding with floodwater and deposition of new alluvial layers on the soil surface. These processes determine the specific features of the alluvial soil composition, the peculiarities of the water conditions and genesis in general.

The alluvial soddy soil develops under the circumstances of short term moistening with floodwater. The groundwater level is deep during the major part of the year, and the capillary fringe is below the soil body; therefore, the biogenic accumulation in the top soil layers is mainly performed owing to the matters contained in the soil body. The dirt deposited on them has light mechanical composition and is normally lean in terms of the alkali and organic matter.

The economic use of the territory is normally limited to the oil and gas extraction, as well as to the prospecting work. No agricultural work is performed on the territory under study. A study on the soil samples was performed according to commonly accepted techniques in an accredited laboratory.

The choice of the observation points was determined with account of the drainage and land runoff features, the location patterns of the manmade objects on the territory, the landscape structure of the territory with account of the spatial differentiation of the natural environment at all levels of the geochemical landscape.

The soil cover was monitored with the visual and instrumental methods. The former consists in inspecting the territory and recording the land disturbance and contamination areas. The latter provides the quantitative and qualitative information on the contaminant content (Kozlovsky, 2003).

Sampling was performed on the plots, which were selected so as to exclude any corruption of the results under the impact of the environment (during dry and still weather), under identical natural conditions with account of the surface runoff direction (Fomin and Fomin, 2001).

According to GOST 17.4.4.02-84, Soil, methods for sampling and preparation of soil for chemical, bacteriological, and helminthological analysis, the size of the sampling plot depends on the research goal. For the goal of determining the content of chemicals in the soil and its physical properties, its size should be equal to $10 \times 10 \mathrm{~m}$. The sampling was performed with a boring bit or a shovel with the envelope method. In order to exclude secondary contamination, the surface of the soil cut or dig wall was scraped off with a polyethylene (polystyrene) knife or a plastic pallet. The samples were taken with clean tools containing no metal. The sampling depth was up to $0.4 \mathrm{~m}$.

The samples were combined into a single sample, $1 \mathrm{~kg}$ in weight, by mixing five spot samples, at least $200 \mathrm{~g}$ each, which was placed in a plastic bag and labeled with a number. The authors filled in the corresponding labels for each soil sample, mentioning the following data in them: date and place of sampling; number and geographic coordinates of the sampling plot; depth of sampling; and the sample number.

The quantitative composition of soil is monitored once a year (in September) by the following physicochemical indicators: nickel, zinc, lead, copper, cadmium, arsenic, mercury, benzopyrene, organic matter, $\mathrm{pH}$, oil, and petrochemicals.

\section{DISCUSSION}

The estimate of the soil cover contamination in the area under study was performed based on the comparison of the data of the physicochemical analysis of the samples with the approved federal and regional sanitary environmental standard specifications for the content of contaminants and indicators obtained during environmental engineering surveys.

The research is aimed at studying the soil cover properties during the oil deposit construction. In the process of hydrocarbon raw material extraction, negative impact on the environment is inevitable, primarily affecting the soil cover. As a result of the impact of various contaminants on the soil, its physicochemical and chemical properties are subject to change (McGill, 1977). Due 
to the specific conditions of formation, the soil cover on the territory under study features weak environmental geochemical resistance to the anthropogenic impacts.

During the research, five soil cover samples were analyzed. On the basis of the performed studies, the values of physicochemical indicators that describe the soil condition on the territory under study were obtained and presented in Table 1.

An analysis of the contaminant content in the area under study showed that the concentrations of petrochemicals according to the Pikovsky's classification (Table 2) conform to moderate contamination in points $\mathrm{P} 1, \mathrm{P} 2, \mathrm{P} 3$, moderately hazardous contamination in point $\mathrm{P} 4$, and highly hazardous contamination in point P5 (Table 2).

The water extract $\mathrm{pH}$ is acidic (between 2.78 and $3.81 \mathrm{pH}$ ), which is determined by intensive exposure of organic acids created as a result of organic residue decomposition. The benzopyrene concentration is below detection threshold (less than $0.01 \mathrm{mg} / \mathrm{kg}$ ).

The concentrations of cadmium $(0.10-0.19$ $\mathrm{mg} / \mathrm{kg}$ ), copper $(2.48-4.94 \mathrm{mg} / \mathrm{kg})$, nickel (1.44$12.50 \mathrm{mg} / \mathrm{kg})$, mercury $(0.082-0.218 \mathrm{mg} / \mathrm{kg})$, lead (3.03-4.62 mg/kg), zinc (3.90-5.92 mg/kg), being the main indicators of negative human impact, are below the detection threshold or low, within the TLV.

The arsenic content in points $\mathrm{P} 1, \mathrm{P} 2, \mathrm{P} 3$ exceeds TLV by 25,43 , and $63 \%$, respectively. In general, the condition of the soil under study is estimated as weakly contaminated.

In order to reduce the impact on the soil cover, the following measures were assumed (Bulatov, Makarenko \& Shemetov, 1999):

- reducing the allocated land by placing facilities in the common corridor of communications;

- placing the designed facility on low-valued land, outside the areas of environmentally valuable forests;

- organizing the works during the winter season;

- organizing waste collection and temporary storage areas;

- recycling industrial and household waste;

- reclaiming the land disturbed during the design facility construction.

In order to reduce the impact on the environment at the construction of approach roads to the valve stations, the following is provided (Bykov, 1991):

- back filling of the road bed on a weak base (peat) without peat reclamation, as a floating

Table 1. Values of the pollutant concentration in soil

\begin{tabular}{|c|c|c|c|c|c|c|c|}
\hline \multirow{2}{*}{$\begin{array}{c}\text { Pollutant } \\
\text { description }\end{array}$} & \multirow{2}{*}{$\begin{array}{c}\text { TLVIALV, } \\
\mathrm{mg} / \mathrm{kg}\end{array}$} & \multicolumn{5}{|c|}{ Soil sample No. } & \multirow{2}{*}{$\begin{array}{l}\text { Backgrounc } \\
\text { value }\end{array}$} \\
\hline & & $\mathrm{P} 1$ & $\mathrm{P} 2$ & P3 & P4 & P5 & \\
\hline $\mathrm{pH}$ (pH units) & - & 3.38 & 3.64 & 3.81 & 2.91 & 2.78 & - \\
\hline Organic matter, \% & - & 72.7 & 81.9 & 63.9 & 76.3 & 78.4 & - \\
\hline Cadmium, mg/kg & 1.0 & 0.15 & 0.15 & 0.19 & 0.15 & 0.10 & 0.13 \\
\hline Copper, mg/kg & 66.0 & 2.78 & 4.38 & 4.94 & 2.83 & 2.48 & 4.80 \\
\hline Arsenic, mg/kg & 2.1 & 3.02 & 3.43 & 2.64 & 1.28 & 1.00 & 4.76 \\
\hline Nickel, mg/kg & 40 & 12.5 & 4.91 & 7.24 & 1.70 & 1.44 & 4.76 \\
\hline Mercury, mg/kg & 2.1 & 0.218 & 0.105 & 0.082 & 0.204 & 0.153 & 0.16 \\
\hline Lead, $\mathrm{mg} / \mathrm{kg}$ & 32.0 & 4.62 & 4.28 & 4.22 & 3.61 & 3.03 & 5.36 \\
\hline Zinc, mg/kg & 100 & 4.75 & 4.86 & 5.92 & 5.24 & 3.90 & 7.30 \\
\hline Petrochemicals, mg/kg & 1000.0 & 823 & 740 & 581 & 1372 & 2585 & 884 \\
\hline Benzopyrene, mg/kg & $<0.02$ & $<0.01$ & $<0.01$ & $<0.01$ & $<0.01$ & $<0.01$ & $<0.01$ \\
\hline
\end{tabular}

Table 2. Petrochemicals standard content scale according to Yu.I. Pikovsky (1993)

\begin{tabular}{|c|c|l|}
\hline \multicolumn{2}{|c|}{ Concentration, $\mathrm{mg} / \mathrm{kg}$} & \multicolumn{1}{c|}{ Contamination estimate } \\
\hline \multicolumn{2}{|c|}{$<100$} & Background content: no environmental hazards \\
\hline \multirow{2}{*}{$100-500$} & $\begin{array}{l}\text { The content is above background values: petrochemicals in such quantity are } \\
\text { actively utilized by microorganisms or washed out by rain flows without human } \\
\text { intervention }\end{array}$ \\
\hline \multirow{3}{*}{$>500$} & $500-1000$ & Moderately contaminated \\
\cline { 2 - 3 } & $1000-2000$ & Moderately hazardous contamination \\
\cline { 2 - 3 } & $2000-5000$ & highly hazardous contamination \\
\hline & $>5000$ & Very severe contamination subject to curing \\
\hline
\end{tabular}


embankment. In order to increase the overall stability of the road bed in the process of consolidation of the weak base (peat shrinkage), it is necessary to lay one layer of $0.18 \mathrm{~m}$ thick plank flooring in the embankment base.

- reducing the impact on the soil cover, enforcing the abidance by the discharge standard specifications and forbidding any machinery passage beside the allocated land allotment for the motor road.

In order to improve the reliability and safety of the pipeline operation, the following decisions were taken (Borodavkin \& Kim, 1981; Mazur, 1990; Lukanin \& Trofimenko, 2001; Perkhutkin, Perkhutkina \& Ovcharuk, 2005):

- accepting the pipeline wall thicker than the design value;

- using the factory-made reinforced anti-corrosion insulation of pipelines and cases for oil and gas pipelines;

- using the pipes made of steel of a higher grade with double-layer polyethylene external coating;

- testing the equipment and pipelines for strength and tightness in order to increase their reliability in operation;

- laying the pipeline underground;

- installing valve stations to turn off sections of the pipeline in case of breaching to ensure faultless operation of the pipelines;

- laying the pipeline through motor roads in protective cases;

- in the process of operation of the designed facility, a thorough scheduled inspection of the flange connections should be provided in order to prevent their loosening and leakage of petrochemicals through them;

- providing communication protection units at the intersection with the existing communication corridors;

- installing line identification signs along the entire pipeline route, on the pipeline turning corners at the intersection of the existing communications, motor roads, water barriers, at each kilometer of the line;

- providing a reliable system for monitoring, control, and protection of technological processes that enables early detection of accident causes at the facilities and their prevention;

- inspecting $100 \%$ of weld joints with the radiographic method.
One of the major impacts on the landscape will be related to the construction of line facilities (Melnikov, 2009). Measures should be taken to prevent or minimize the possible development of the soil erosion. Increased erosion can occur along roads and on slopes.

The main activities aimed at preventing and minimizing the negative impacts on soil and measures for the preservation of the hydrological condition consist in the selection and implementation of optimal (from the perspective of environment protection and management) solutions (Plyusnin \& Golovanov, 1983):

- organizing the surface runoff, creating a drainage collection network to prevent water erosion and uncontrolled washing-out of surface sand deposits;

- compacting the soil when filling pits and trenches to the level of undisturbed structure to prevent any subsidence on the area surface;

- observing the norms and rules of construction, including the observance of land acquisition and eliminating the soil disturbance outside the land acquisition area;

- prohibiting any movement of heavy vehicles outside the roads and areas of the agreed land allotment to prevent erosion;

- stabilizing the soil by technical means as thoroughly as possible (using rock riprap, peat covers, accelerated grassing or other erosion prevention measures);

- landscaping slopes;

- selecting the most suitable time for work. When the ground is frozen in the winter, the erosion intensity is lower;

- using concrete slabs for floors during the construction works in order to reduce the impact on the soil cover;

- reclaiming the disturbed land.

- During the operation, continuous monitoring and diagnostics of the pipeline will be implemented that will ensure the trouble-free operation.

\section{CONCLUSION}

All the above-mentioned technical and organizational solutions contribute to the prevention of land contamination. In case of emergency, the damage to land resources and soil will be prevented by performing the emergency response actions and implementing measures according to the plan 
of accident elimination plan indicating the number and the appointment of the staff.

Thus, the implementation of the technical and environmental solutions will ensure a reliable operation of the facilities located in the field. The impact on the environment during the construction and normal operation will be minimal.

The main activities aimed at preventing and minimizing the negative impact on the geological environment consist in choosing and implementing the best (from the perspective of environment protection and management) solutions, technological regulations and safety rules (Konyukhov \& Bratishko, 1985; Milyutin, Androsova \& Kalinin, 2007):

- using non-frost heaving soil for back filling (sandy soil from a quarry);

- providing technical soil amelioration in the substrates of the critical structures;

- substituting the soil or providing a heat-insulating bedding on the development areas with the surface consisting of loosely bound soil (peat, etc.);

- placing and arranging temporary warehouses of fuel and lubricants, materials used in the construction in strict compliance with the relevant rules and regulations that prevent any groundwater contamination;

- preventing accumulation of industrial and domestic waste at the catchment areas and in the locations of groundwater used for drinking or industrial water supply;

- ensuring complete exploration work in the subsoil area.

The main requirements for the rational use and protection of soil quarries (sand, peat), used in construction and reclamation (Illarionov, 2004; Melkozerova, 2007) are:

- ensuring complete geological survey and rational complex use of mineral resources;

- accounting the soil reserves, both extracted and left in the depths;

- preventing the subsurface contamination from wastewater discharge;

- using the soil reserves efficiently, as well as maintaining non-commercial reserves in the interior or their stocking for later industrial development;

- reclamation of disturbed land and bringing them in a condition suitable for further use (Anderson, Mukatanov \& Boiko 1980).
At the time of the field facility construction, modern technologies and equipment will be applied to ensure fire protection, as well as the operational and environmental safety of the facility. Thus, the impact on the soil cover during the oil field construction will be short and limited to the construction period. During the operation of the oil field facilities, no additional impact on soil will occur provided all rules and regulations are complied with.

\section{REFERENCES}

1. Amakiri, J.O. \& Onofeghara, F.A. 1984. Effects of crude oil pollution on the germination of Zea Mays and Capsikum frutescens. Enwiron. Pollut., A 35(2), 159-167.

2. Anderson, R.K., Mukatanov, A.Kh. \& Boiko, T.F. 1980. Environmental consequences of the soil contamination with oil. Ecology, 6, 21-25.

3. Bezuglova, O.S. 2009. Soil classification. Study guide for students of higher educational institutions. Southern Federal University, Rostov-on-Don.

4. Borodavkin, P.P. \& Kim, B.I., 1981. Environment protection at the construction and operation of main pipelines. Nedra, Moscow.

5. Bulatov, A.I., Makarenko, P.P. \& Shemetov, V.Yu. 1999. Reference book for environment engineers in the oil extracting industry about the environment contaminant analysis methods: in 3 volumes. Part 2 - Soil. Nedra Business Center Ltd., Moscow.

6. Bykov, I.Yu. 1991. Methods for environmental protection of the Far North at well construction. The Publishing House of the Leningrad University, Leningrad.

7. Cherkashenina, E.F. (ed.) 1972. Agricultural and climatic resources of the Tyumen region. Gidrometeoizdat, Leningrad.

8. Egorov, V.V. 1977. Classification and diagnostics of soil in the USSR. Kolos, Moscow.

9. Fomin, G.S. \& Fomin, A.G. 2001. Soil. Quality and environmental safety control under international standards. The Protektor Publishing House, Moscow.

10. Hutchinson, T.S. \& Freedman, W. 1978. Effects of experimental crude oil spills on subarctic boreal forest vegetation near Normal Wells, N.W/T., Canada. Canadian Journal of Botany, 56(19), 2424-2433.

11. Illarionov, S.A. 2004. Environmental aspects of oil-contaminated soil recovery. Ural Department of RAS, Yekaterinburg.

12. Konyukhov, A.V. \& Bratishko, Yu.A. 1985. Environment protection at prospecting surveys in the Far 
North regions. VNNIIOENG, Moscow.

13. Kozlovsky, F.I. (2003). Theory and methods for soil cover studies. Geos, Moscow.

14. Lukanin, V.N. \& Trofimenko, Yu.V. 2001. Industrial and transport ecology. Textbook for higher school. Vyshshaya Shkola, Moscow.

15. Mazur, I.I. 1990. Environmental engineering solutions in the construction of oil and gas facilities. Nedra, Moscow.

16. Mcgill, W.W. 1997. Soil restoration following oil spills - a review. J. Canad. Petrol. Technol., 16(2), 60-67.

17. Melkozerova, V.M. (ed.) 2007. Environment protection and rational environmental management: Reference book. SFU, Krasnoyarsk.

18. Melnikov, A.A. 2009. Problems of the environment and the strategy of its preservation: study guide for academic organizations. Akademichesky Proekt, Gaudeamus, Moscow.

19. Milyutin, A.G., Androsova, N.K. \& Kalinin, I.S. 2007. Ecology: Geoecology of subsurface resource management: textbook. Vyshshaya Shkola, Moscow.

20. Parfenov, V.G. \& Sivkov, Yu.V. 2015a. Geoecology:
Study Guide. The Publishing House of FSBEIHE Tyumen State Oil and Gas University, Tyumen.

21. Parfenov, V.G. \& Sivkov, Yu.V. 2015b. Reclamation of land contaminated with oil. The Publishing house of FSBEIHPE Tyumen State Oil and Gas University, Tyumen.

22. Perkhutkin, V.P., Perkhutkina, Z.I. \& Ovcharuk, T.A. 2005. Reference book for environment protection engineers (ecologists). Infra Inzheneriya, Moscow.

23. Pikovsky, Yu. I. 1993. Natural and anthropogenic flows of hydrocarbons in the environment. The Publishing House of MSU, Moscow.

24. Plyusnin, I.I. \& Golovanov, A.I. 1983. Ameliorative soil science. Kolos, Moscow.

25. Podavalov, Yu.A. 2010. The ecology of oil and gas production. Infra Inzheneriya, Moscow.

26. Shumanova, A.A. (ed.) 1965. Reference book on the climate in the USSR. Issue 17. Omsk and Tyumen Oblasts. Part 2. Air and soil temperatures. HydroMeteorological Publishing House, Leningrad.

27. Tetelmin, V.V. \& Yazev, V.A. 2009. Environment protection in the oil and gas industry. Study Guide. The Intellekt Publishing House, Dolgoprudny. 